\title{
Magnetic resonance imaging findings of Susac syndrome
}

\author{
Susac sendromunun manyetik rezonans görüntüleme bulgulart \\ Güliz Yılmaz, Işıl Başara*, Gülgün Yılmaz Ovalı, Serdar Tarhan, Yüksel Pabuşcu, \\ Hatice Mavioğlu
}

Department of Radiology (G. Yılmaz, MD, I. Başara, MD, Assoc. Prof. G. Y. Ovalı, MD, Prof. S. Tarhan, MD, Prof. Y. Pabuşcu, MD), Department of Neurology (Prof. H. Mavioğlu, MD), Celal Bayar University School of Medicine, TR-45030 Manisa

\begin{abstract}
Susac syndrome is a rare disease of unknown pathogenesis. It is caused by a microangiopathy affecting the arterioles of the brain, retina, and cochlea, giving the classic clinical triad of subacute encephalopathy, visual loss secondary to retinal branch occlusions, and sensorineural hearing loss. Magnetic resonanace imaging, retinal fluorescein angiography, and audiography findings enable diagnosis. Early therapy may reduce sequelae and improve recovery. Herein we report a case of Susac syndrome with all the findings of the disease.
\end{abstract}

Keywords: Magnetic resonance imaging, microangiopathy, Susac syndrome

\section{Özet}

Susac sendromu patogenezi bilinmeyen nadir bir hastalıktır. Beyin, retina ve kohleanın etkilendiği mikroanjiyopati sonucunda ortaya çıkar. $\mathrm{Bu}$ durum hastalığın tipik triadı olan subakut ensefalopati, retinal arteriollerin tıkanmasına bağlı oluşan görme kaybı ve sensorinöral işitme kaybına neden olur. Manyetik rezonans görüntüleme, retinal floresan anjiografi ve odyografi bulguları tanıya yardımcıdır. Erken tedavi sekel oluşumunu azaltabilir ve iyileşemeyi hızlandırabilir. $\mathrm{Bu}$ yazıda hastalığın tüm bulguları ile birlikte bir Susac sendromlu olguyu sunuyoruz.

Anahtar sözcükler: Manyetik rezonans görüntüleme, mikroanjiyopati, Susac sendromu

Geliş tarihi/Received: December 04, 2011; Kabul tarihi/Accepted: January 18, 2014

\section{*Corresponding author:}

Dr. Işıl Başara, Radyoloji Anabilim Dalı, Celal Bayar Üniversitesi Tıp Fakültesi, TR-45030 Manisa. E-mail: slbasara@yahoo.com

\section{Introduction}

Susac's syndrome is an uncommon neurologic disorder of unknown cause. It has been described as a clinical triad of encephalopathy, hearing loss, and branch retinal artery occlusions [1]. This syndrome was first described by John O. Susac in 1979 in two young women presenting with the classic clinical triad of subacute encephalopathy, retinal arteriolar branch occlusions, and sensorineural hearing loss [2]. Clinically, the diagnosis is difficult when the patient presents with only a portion of the triad. Radiologist plays an important role when the disease is suspected. In this circumstance, magnetic resonance imaging (MRI) may be crucial in aiding the neurologist to make the diagnosis. Neuroradiologists and general radiologists frequently attribute the MRI findings seen in patients with Susac's syndrome to multiple sclerosis or acute disseminated encephalomyelitis. Herein we aimed to present the MRI findings of a case with Susac syndrome. 


\section{Case report}

In September 2011, 24-year-old female patient appilied to ophthalmology out-patient clinic with increasing vision loss lasting a few months. The patient with accompanying hearing loss was redirected to neurology out-patient clinic for concultation.

She did not have similar disease history in her family and migren. When she was 7 years old, she had been diagnosed as meningitis and treated at intensive care unit. During treatment, she could not recognize her mother and approximately for 20 days, she had been evaluated with loss of movement. After treatment, hearing loss had been determined as sequelae in her right ear.

In the last 2 years, she had complaints such as slowing in her movements, draging her right lower extremity and increasing vasculary type head ache. During this time, hearing loss has developed in her left ear. Four years ago, she had started to suffer from learning, memorizing difficulties and nervousness.

Two months ago, she had fallen down and hit her head. One day after this trauma, there was vision loss in the upper half of her right eye. Despite the treatment, findings had not regressed, in ophtalmologic evaluation, upper nasal quadrantnopia had been found.

In present evaluation, optic disc and neurological findings were normal, visual acuity was complete. Electroencephelography (EEG), electromyography (EMG) findings were normal. In visual evoked potential (VEP) there was advanced slowing $(216 \mathrm{~ms})$. There was bilaterally sensorineural hearing loss (left, at low frequency, right, at all frequencies). In fundus examination, macula was normal. There was perivasculary cuffing in temporal part of fovea secondary to previous vasculitis (Figure 1a). Retinal fluorescein angiography revealed filling defect at the temporal lower half of the right eye (Figure 1b).

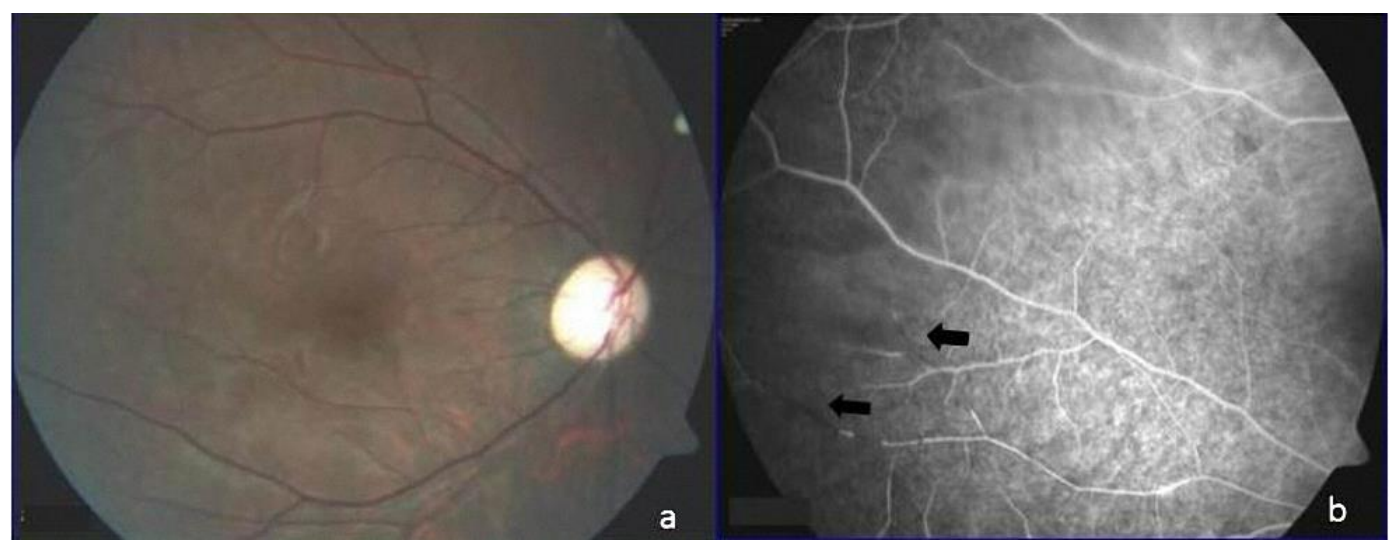

Figure 1 a. In fundus examination, macula was normal. There was perivasculary cuffing in temporal part of fovea secondary to previous vasculitis. b. Retinal fluorescein angiography revealed filling defect at the temporal lower half of the right eye (Black arrows).

With these findings, she was referred to our MRI section for cranial MRI examination. In T2-weighted and FLAIR sequances there were hyperintense lesions in both periventriculary white matters and corpus callosum. After contrast administration, the lesions did not enhance. Imaging findings of lesions and their discriminations were similar to demyelizing plaques and vasculitis (Figure 2 and 3 ). 


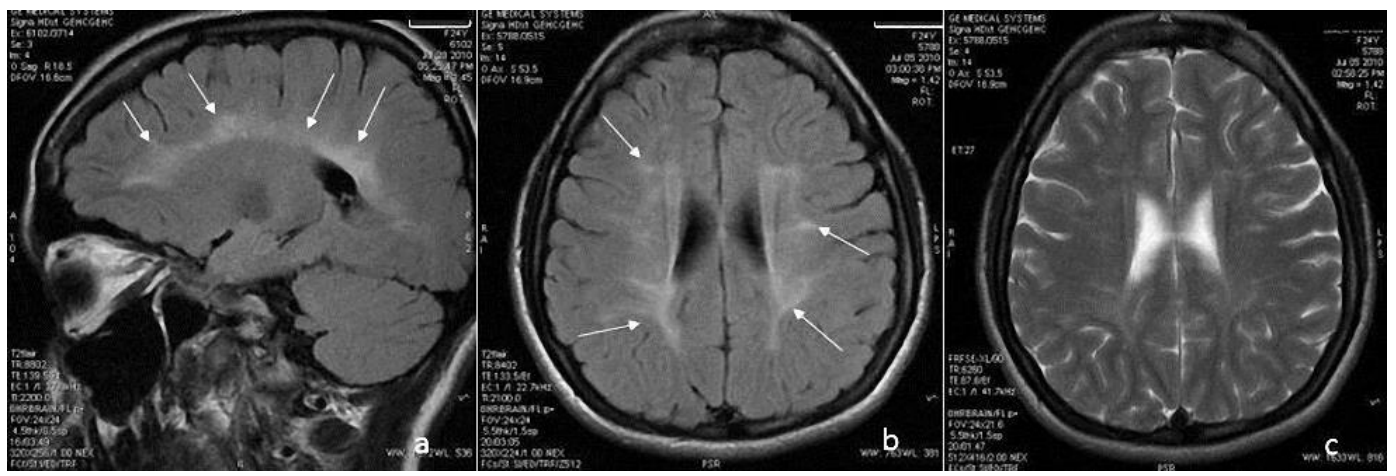

Figure 2. In a. Sagittal FLAIR, b. Axial FLAIR and c. T2-weighted MRI images there are hyperintense foci in perivantriculary zones and corpus callosum (White arrows).

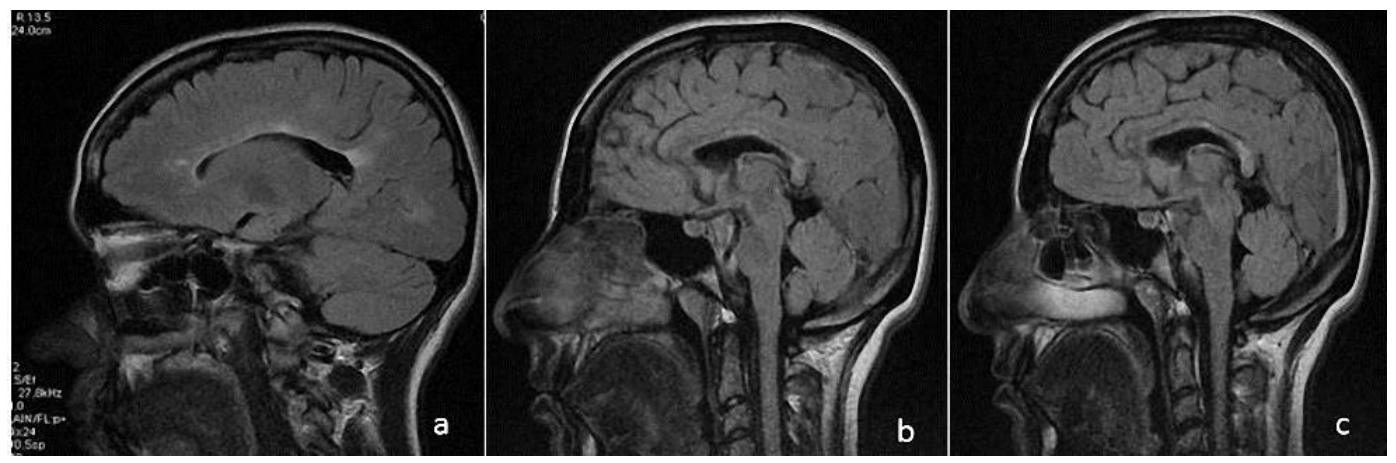

Figure 3. In a. Sagittal FLAIR, b. Sagital precontrast T1-weighted and c. Sagital postcontrast T1-weighted MRI images, there are no markedly enhancement.

Our case was diagnosed as Susac syndrome with MRI findings, sensorineural hearing loss and retinal artery occulions.

\section{Discussion}

Susac had first described this pathology, in 1979 with two different female patients who had applied with encephelopthy, retinal artery occulusion and deafness findings. In 1986, Hoyt had named this pathology as 'Susac syndrome' [3]. Mass et al. [4], had described this pathology by using the first letters of the findings such as RED-M (retinopathy, encephelopathy, deafness- microangiopathy) [5]. Schwitter et al. [6] had named this syndrome as SICRET (small infarcts of cochlear, retinal, and encephalic tissues), Petty et al. [7], had described as 'retinocochleocerebral vasculopathy'.

In the literature, most of the cases are between 18-40 years old, healthy female patients with no family history [8]. The disease is very rare and only less than 100 cases have been reported in the literatue. Usually, it may be interfered with multiple sclerozis, migren, lupus erythematosus, encephalitis, Meniere disease, thromboembolic infarcts and even schizophrenia [7, 9].

Usually there are active monophasic limiting stages of the disease lasting months and years [9]. As a result of these stages, functional and residual defects can be seen.

Audiometry reveals sensorineural hearing loss that is usually in the low-frequency to midfrequency range. The associated retinopathy is characterized by multiple peripheral retinal arteriolar branch occlusions that can be seen at ophthalmoscopic examination or retinal fluorescein angiography [10-12].

MRI is the referred imaging method for diagnosis. In T2-weighted images, there are many, milimetric, hypertintensities. In postcontrast images, there are diffuse enhancement 
in gray and white matters of cerebrum-infratentorial. In acute and subacute stages, the lesions can enhance [7, 8, 11]. Lesions are seen in corpus callosum (genu, corpus and splenium), centrum semiovale, internal capsule, perivantriculary white matter, brain stem, cerebellum, cerebral and cerebellar periventriculary pedincules, basal ganglia and thalamus. These lesions may appear on T1-weighted MRI as hypointense areas during the subacute or late phase of disease, as in this patient. They usually evolve into microinfarction cysts in the late stage of disease. The most striking MRI finding in patients with Susac syndrome is the involvement pattern of the corpus callosum $[3,8,9$, 11]. No abnormal signal intensity and enhancement in cochlea have not been reported in the literature. Cerebral atrophy can be seen in the late stages of the disease. Computed tomography and angiography examinations are applicated for differential diagnosis [7, $11]$.

In our case cranial MRI findings were competible with the literature but the lesions were generally patchy and the margins of the lesions were insignificant. All of the lesions were mainly in periventricular and corpus callosum regions. There was cranial atrophy additionally. These findings depend on chronic pattern of the disease. Susac syndrome often has a chronic relapsing course punctuated by frequent remissions and exacerbations for 1-2 years [13, 14]. After contrast material administration, there was no enhancement. Retinal fluorescein angiography was performed after recognition of the brain MRI findings. This examination revealed inflamed retinal arterioles with filling defect at the temporal lower half of the right eye indicating vasculitis. In audiometric evaluation there was hearing loss in both ears. These findings were also competible with the literature. All these MRI, retinal floroscein angiography and audiometry findings have lead us to the Susac syndrome diagnosis.

Susac syndrome can mimic several diseases. The differential diagnosis includes any disorder that can produce multifocal neurologic symptoms, visual impairment, hearing loss, or any combination of these and is therefore very large: Demyelinating disease, connective tissue disease, infection, neoplasm, procoagulant state, and ischemic disease of different etiologies. Several central nervous system infections can cause multifocal neurologic signs, including loss of hearing. The infections may be associated with meningitis, so cerebrospinal fluid examination can help in the detection of microorganisms. Angiography may show abnormalities of arteries at the base of the brain, whereas this examination is usually normal in patients with Susac syndrome [12].

Cranial MRI, retinal floroscein angiography and audiologic examinations give us great contribution to the diagnosis. As a result of this early treament regimes can be applicated. All the patients with Susac syndrome prediagnosis should be evaluated with clinical, imaging, retinal floroscein angiography and audiometric examinations.

\section{Refeneces}

1. Susac JO, Murtagh FR, Egan RA, Berger JR, Bakshi R, Lincoff N, Gean AD, Galetta SL, Fox RJ, Costello FE, Lee AG, Clark J, Layzer RB, Daroff RB.MRI findings in Susac's syndrome. Neurology 2003; 61: 1783-7.

2. Susac JO, Hardman JM, Selhorst JB. Microangiopathy of the brain and retina. Neurology 1979; 29: 313-6.

3. Susac JO. Susac's syndrome: the triad of microangiopathy of the brain and retina with hearing loss in young women. Neurology 1994; 44: 591-3.

4. Mass M, Bourdette D, Bernstein W, Hammerstad J. Retinopathy, encephalopathy, deafness associated microangiopathy (the RED M syndrome): three new cases. Neurology 1988; 38(Suppl): 215.

5. Nicolle MW, Mclachlan RS. Microangiopathy with retinopathy, encephalopathy, and deafness (RED-M) and systemic features. Semin Arthritis Rheum 1991; 21: 123-8.

6. Schwitter J, Agosti R, Ott P, Kalman A, Waespe W. Small infarctions of cochlear, retinal, and encephalic tissue in young women. Stroke 1992; 23: 903-7. 
7. Petty GW, Engel AG, Younge BR, Duffy J, Yanagihara T, Lucchinetti CF, Bartleson JD, Parisi JE, Kasperbauer JL, Rodriguez M. Retinocochleocerebral vasculopathy. Medicine (Baltimore) 1998; 77: 12-40.

8. Papo T, Biousse V, Lehoang P, Fardeau C, N'Guyen N, Huong DL, Aumaitre O, Bousser MG, Godeau P, Piette JC. Susac syndrome. Medicine (Baltimore) 1998; 77: 3-11.

9. Petty GW, Matteson EL, Younge BR, McDonald TJ, Wood CP. Recurrence of Susac syndrome (retinocochleocerebral vasculopathy) after remission of 18 years. Mayo Clin Proc 2001; 76: 958-60.

10. Barker RA, Anderson JR, Meyer P, Dick DJ, Scolding NJ. Microangiopathy of the brain and retina with hearing loss in a 50 year old woman: extending the spectrum of Susac's syndrome. J Neurol Neurosurg Psychiatry 1999; 66: 641-3.

11. O'Halloran HS, Pearson PA, Lee WB, Susac JO, Berger JR. Microangiopathy of the brain, retina, and cochlea (Susac syndrome). A report of five cases and a review of the literature. Ophthalmology 1998; 105: 1038-44.

12. Do TH, Fisch C, Evoy F. Susac syndrome: report of four cases and review of the literature. AJNR Am J Neuroradiol 2004; 25: 382-8.

13. Saw VP, Canty PA, Green CM, Briggs RJ, Cremer PD, Harrisberg B, McCluskey P, O'Day J, Paine M, Wakefield D, Watson JD. Susac syndrome: microangiopathy of the retina, cochlea and brain. Clin Experiment Ophthalmol 2000; 28: 373-81.

14. Yellin MW, Johnson TW. A case of Susac syndrome. J Am Acad Audiol 2000; 11: 484-8. 